\title{
The game as strategy for approach to sexuality with adolescents: theoretical-methodological reflections
}

\author{
O jogo como estratégia para abordagem da sexualidade com adolescentes: reflexões teórico-metodológicas \\ El juego como estrategia de abordaje de la sexualidad en los adolescentes: reflexiones teórico-metodológicas
}

\section{Vânia de Souza', Maria Flávia Gazzinelli", Amanda Nathale Soares'II, Marconi Moura Fernandes"', Rebeca Nunes Guedes de Oliveiralv ${ }^{\mathrm{IV}}$, Rosa Maria Godoy Serpa da Fonsecav}

\author{
' Universidade Federal de Minas Gerais, Nursing School, \\ Department of Maternal-Child Nursing and Public Health \\ Belo Horizonte, Minas Gerais, Brazil.
}

"Universidade Federal de Minas Gerais, Escola de Enfermagem, Department of Applied Nursing. Belo Horizonte, Minas Gerais, Brazil.

II' Universidade Federal de Minas Gerais, Nursing School, Postgraduate Program in Nursing. Belo Horizonte, Minas Gerais, Brazil. Iv Universidade de São Paulo, Nursing School, Department of Nursing in Collective Health. São Paulo, Brazil.

${ }^{\vee}$ Universidade de São Paulo, Nursing School, Department of Public Health. São Paulo, Brazil.

How to cite this article:

Souza V, Gazzinelli MF, Soares AN, Fernandes MM, Oliveira RNG, Fonseca RMGS. The game as strategy for approach to sexuality with adolescents: theoretical-methodological reflections.

Rev Bras Enferm [Internet]. 2017;70(2):376-83. DOI: http://dx.doi.org/10.1590/0034-7167-2016-0043

Submission: 03-28-2016 Approval: 12-02-2016

\begin{abstract}
Objective: To describe the Papo Reto [Straight Talk] game and reflect on its theoretical-methodological basis. Method: Analytical study on the process of elaboration of the Papo Reto online game, destined to adolescents aged 15-18 years, with access to the Game between 2014 and 2015. Results: the interactions of 60 adolescents from Belo Horizonte and São Paulo constituted examples of the potentialities of the Game to favor the approach to sexuality with adolescents through simulation of reality, invention and interaction. Based on those potentialities, four thinking categories were discussed: the game as pedagogic device; the game as simulation of realities; the game as device for inventive learning; and the game empowering the interaction. Conclusion: By permitting that the adolescents take risks on new ways, the Game allows them to become creative and active in the production of senses, in the creation of their discourses and in the ways of thinking, feeling and acting in the sexuality field. Descriptors: Adolescents; Games and Toys; Sexuality; Education in Health; Educational Technology and Public Health.
\end{abstract}

\section{RESUMO}

Objetivo: descrever o jogo Papo Reto e refletir sobre suas bases teórico-metodológicas. Método: estudo analítico sobre o processo de elaboração do jogo on-line Papo Reto, destinado a adolescentes de 15 a 18 anos, com acesso ao Jogo entre 2014 e 2015. Resultados: as interações de 60 adolescentes de Belo Horizonte e de São Paulo constituíram exemplos das potencialidades do Jogo para favorecer a abordagem sobre sexualidade com adolescentes por meio da simulação de realidades, da invenção e da interação. Com base nessas potencialidades, quatro categorias reflexivas foram discutidas: o jogo como dispositivo pedagógico; como simulação de realidades; como dispositivo para a aprendizagem inventiva; e o jogo potencializa a interação. Conclusão: ao permitir que os adolescentes se arrisquem por novos caminhos, o Jogo possibilita que se tornem criativos ativos na produção de sentidos, na criação de seus discursos e nas formas de pensar, sentir e agir no campo da sexualidade.

Descritores: Adolescente; Jogos e Brinquedos; Sexualidade; Educação em Saúde; Tecnologia Educacional e Saúde Pública.

\section{RESUMEN}

Objetivo: describir el juego Papo Reto, y aportar reflexiones desde sus bases teórico-metodológicas. Método: estudio de análisis sobre el proceso de elaboración del juego en línea Papo Reto, destinado a los adolescentes de 15 a 18 años, y que lo accedieron entre 2014 y 2015. Resultados: las interacciones de sesenta adolescentes de la ciudad de Belo Horizonte y São Paulo mostraron 
potencialidades de este juego en abordar la sexualidad en adolescentes a través de la simulación de realidades, creación e interacción. En base a estas potencialidades se han puestas en discusión cuatro categorías: el juego como herramienta pedagógica; como simulación de realidades; como herramienta de aprendizaje inventiva y como el que promueve la interacción. Conclusión: por permitir que los adolescentes se arriesguen en nuevos caminos, el juego les ayuda a convertirse en seres creativos activos en la producción de sentidos, en la creación de sus discursos y en las formas de pensar, sentirse y actuar en el tema de la sexualidad. Descriptores: Adolescente; Juegos y juguetes; Sexualidad; Educación en Salud; Tecnología Educacional y Salud Pública.

\section{CORRESPONDING AUTHOR Vânia de Souza E-mail: vaniaxsouza@yahoo.com.br}

\section{INTRODUCTION}

In Brazil, the sexuality theme has been focus of public policies implementation, aiming at the reduction of damages to the adolescents' health. Among them, one highlights the Health and Prevention in Schools Project (Saúde e PrevençãonasEscolas - SPE), inserted into the Health in School Programme. Nationally comprehensive, the SPE objectifies to stimulate actions to the promotion of health in sexual and reproductive fields; to amplify partnerships between schools and other institutions, aiming at the integral formation of this public; and to promote the participation of adolescents and youths as agents that transform the reality ${ }^{(1)}$.

Despite these initiatives, there are still important limitations to reach these results ${ }^{(2)}$. The approach, in general, is vertical, based on the transmission of information and directed strictly to biological aspects, under the perspective of the doctor-hygienist paradigm. For the purpose of assuring assimilation and memorization of contents, considered necessary by the educator, the discourses are many times marked by implicit, regulator and definitive rules ${ }^{(3-4)}$. They reinforce trues seen as unique and inhibit the active participation of adolescents, the exchange of experiences and the understanding of their existence.

In order to face this reality, it is indispensable to seek pedagogic strategies that do not consider only the cognitive dimension of learning, but that stimulate the critical-reflexive and favor the interaction and the production of ways of subjectification $^{(5)}$. In this perspective, the pedagogic strategy in game format manifests alternative with potential to establish a problem-based perspective, able to mobilize the players in their desires and experiences and favor the invention ${ }^{(6-8)}$, used here for the approach to the sexuality with adolescents.

The objective in this study is to describe the Papo Reto Game and reflect on its theoretical-methodological basis.

\section{METHOD}

\section{Ethical aspects}

The project was approved by the Research Ethics Committees of Federal University of Minas Gerais and University of São Paulo.

\section{Type of study, scenario and participants}

It is an analytical study, developed during the process of elaboration of the Game and its first execution by 60 secondary education adolescents from public schools, being one school from Belo Horizonte and another from São Paulo. The Game was made available to adolescents aged 15-18 years, between 2014 and 2015, with predominance of 18-year-old players.

The inclusion criteria of the participants in the Game were as follows: adolescents aged between 15-18, their interest, the presentation of the Adolescent Informed Consent Form signed by the adolescent and the Informed Consent Form signed by the mother, father or legal guardian for the ones aged below 18, there being no other inclusion/exclusion criteria.

\section{Analytical categories}

The interactions of the adolescents that participated in the Game constitute examples of its potentialities to favor the approach to sexuality with adolescents through simulation of realities, invention and interaction.Such potentialities were analyzed based on notes about the sociology and the theory of games ${ }^{(9)}$, inventive learning ${ }^{(10)}$ and social interaction in the construction of knowledge ${ }^{(11)}$. One elected as specified categories: the game as pedagogic device; as simulation of realities; as device for inventive learning; and it as device of interaction for production of knowledge.

\section{Game design}

Papo Reto is an online game, with approach to sexuality and gender relations. The player subscribes for the game, chooses a nickname and an avatar (corporeal manifestation of someone on the cyberspace) and can stay on the Game as long and as many times as desired, due to the fact it is continuous, without time access limit. The game symbolizes a city composed of Home, School, Internet, Parties and Street, unblocked progressively by the payers' scores. One presents problem situations so that the participants discuss, propose and share with their pairs their way of thinking and acting. Most situations are from real life and others from Internet, TV, books and magazines, and one has privileged themes of difficult approach in family, school, health services and even among friends, such as violence in intimacy relations, sexual diversity, pedophilia, the first kiss and sex under different ways. There is also the possibility for the player to post his/her own situations when achieving the status of Collaborator in each scenario, allowing the Game to be fed by the players themselves.

Initially, Papo Reto was designed for adolescents aged 1418 years, considering the average age of sexual initiation indicated in several studies with the Brazilian population ${ }^{(12-14)}$; the 18-year- old extreme defined for adolescence by the Child and Youth Statute [Estatuto da Criança e Adolescente - ECA $]^{(15)}$; and the content to be approached. After the validation of the Game Design by a group of specialists, through the workshop 
technique, the age group of 15 to 18 years old was considered more pertinent for secondary education students, considering the diversity of themes and the crescent levels of profundity and complexity of the situations presented.

The Game Design was analyzed by Consultancy Group, with the participation of teachers, researchers and specialists in the fields of sexuality, adolescence, gender, games, scenic arts and games design, from different institutions, cities and states. With the creation of the Game there was the second phase of validation of Papo Reto in relation to divulgation, fruition, relaxation, applicability, playfulness, to the limits and the possibilities for the adolescents' autonomy and protagonism in the affective-sexual field. This phase was carried out through submission of an online form for professionals who are specialists in the fields of sexuality (Specific Group), many of them participants in the Consultancy Group, with the minimal graduation being doctorate and higher education in Nursing, Psychology, Pedagogy, Biological Sciences and performance in teaching and research fields.

\section{RESULT}

\section{The Game as pedagogic device}

Based on its characteristics and potentialities, as well as on the answers and the ways of interaction between the participating adolescents, the Papo Reto Game is conceived as pedagogic device. Conceiving it as device implies put it in condition of heterogeneous setting producer of innovations that generate events and transformations through the updating of virtualities.

In Papo Reto, in some situations, the game device connects to the sexual difference device, constituted by the legitimation of normative systems of sex-gender that limits the notion of difference to a binary matrix man-woman. This connection between devices may be witnessed in one of the problem situations presented in Papo Reto Game, where one approaches the case of a boy who has tried to go to school wearing feminine clothes. The boys are questioned if the boy should or not be allowed to attend such space wearing those clothes.

As answer to this situation, an adolescent said:

No. I think we should wear uniforms in order no to happen situations like this. (Negro do Poder - 16 years old).

Because it is a Game that does not predefine ways of experience, this adolescent, projected into his character, ratifies instituted discourses of coercion and non acknowledgment of differences, being empowered by others who agree with him.

For other adolescent, the boy:

Should be allowed, because everyone dresses the way hel she wants, to feel comfortable. Clothes are just clothes, a piece of fabric beautifully sewn. For what purpose does one dictate rules for what is right for each gender? (Ramona Flowers - 15 years old)

Contrary to the first, the latter answer is open for the production of singularities and other ways of being. By introducing irregularities, the player created dislocations in sex-gender normative systems, opening possibilities for the decomposition of the binary matrix man-woman and of the compulsory heterosexuality.

\section{The game as simulation of realities}

Papo Reto simulates realities in which the adolescent plays as boy, girl, an androgynous being or a soulwithout sex definition. Represented by his/her avatar, the player has access to the game's scenarios, whose approached themes have been previously defined. In the Home scenario, for instance, there are themes about the relation with the body and the dialog with parents. The Street, the last scenario to be achieved on the Game, is the only environment in which there are no pre-established themes, with possibilities of insertion of any subject.

In the post of an adolescent that achieved the status of Collaborator (who may create new situations for the game) in the Home scenario, the theme inserted was Sex Games, with the following situation:

You and your boyfriend (girlfriend) have been together for a while, then he (she) sees in a movie two people playing body banquet, where food is poured on the naked body of one of the two. You think it is exciting and he (she) proposes doing the same. You... (Steven - 18 years old)

When creating or answering to an unusual situation, the player simulates to act in a known - or experienced - reality. Thus, he/she dissimulates the reality, simulating other one, in which invites another player to believe, for a while, that the "real is more real than the real", as observed in the following answers:

I would go to the supermarket. (Ramona Flowers - 15 years old)

No, I do not think it is hygienic. (Luvatic - 16 years old)

I say that I am not ready, although I think it is very exciting. (Isa - 16 years old)

The potentiality of Papo Reto is in the experience of projection of the self in several simulated, provocative and mobilizing realities. Interpreting "other self", the player may invent, discover or rediscover necessities, desires and ways of dealing with sexuality.

The system of the Papo Reto Game is also product of realities simulation that is proper to it. The player not only simulates other ways of being, reacting and interacting, but also experiences the simulation in the objective elements of the game, as in the case of scoring. The player scores by answering to the questions - which may be open or closed. The game is developed by sharing the answers and by the analysis of them by the pairs. The players with higher scores are the ones who more interact and provoke interactions, impelling the others to analyze their answers - Liking, Disliking, Commenting - or answering to the situations posted by them. All those ways of interaction are scored. The score simulates the production of the way the players interact. One Like, for instance, suggests that the player simulated to agree with the other. The score is an element that expresses continuity to the "make-believe."

In the game, there are also two support areas to the player, which do not generate scoring - the area "Do you catch on?" and "Where to seek help?" -, created for the search for knowledge, 
support or deepening of specific subject, according to the interest or the curiosity promoted. In the area "Do you catch on?" there are tips, illustrations, definitions and curiosities about several subjects, such as body care, ejaculation, intimate waxing and more philosophic discussions about love and the relations of gender as a social construct. In the tab "Where to seek help?" one provides telephone numbers and addresses of services as Tutelary Councils, attendance to violence cases and primary assistance to health. The access to these areas works as a game effect that may indicate the potency of the interactions and situations approached for the search for knowledge

\section{The game as device for inventive learning}

Conceived as pedagogic device, Papo Reto allows the invention of other forms to deal with sexuality. It potentizes the inventive learning, which happens in the shock with the signs of the world. The situations of the daily routine brought to the game, apparently superficial and insignificant, appear rich in signs. By experiencing the situations proposed, the adolescents are seduced by the signs that emanate from them, throwing themselves into the adventure of trying to decipher them.

Example of a situation from the School scenario is Andy's case, a happy girl, spontaneous, who likes wearing short and low-cut clothes and happens to be called "hoochie" by colleagues. Sometimes, Andy gets upset, but, at the same time, does not think it is correct to give up what she likes to please other people. To the players, it is questioned "as Andy's best friend, what would you say to her?"

The answers given to the proposition "as Andy's best friend, what would you say to her?" express the starting point to decipher the true sign, as observed in the answers of these players.

For her to stop being a slut. (Setepego, teenvergo - 18 years old)

For her, at least, to avoid this kind of clothes in places where they are not proper. (Giihsiqueira - 18 years old)

For her to keep on wearing what she likes and do not take into account what they say: let them say, they speak, they think. (Lele -16 yearsold)

The way she dresses does not define her, and that she can wear the clothes she wants and nobody has anything to do with this. Andy, you rock, keep being this way, you do not have to give up anything - your body your rules. (Ramona Flowers - 15 years old)

Mentioning themes as exposition of woman body, decorum and vulgarity, the answers were from positioning radically against Andy's attitude, passing by recommendations up to unrestricted support to her way of dressing and acting.

Coherently, these answers include notions permeated by stereotypes and prejudices, which seem to originate from exercises of recognition, as well as notions that seek to violate the immediate manifested sign, signalizing to the movements of intervention and construction of new rules for the ways of being.

In recognition, as it can be noticed in the two first answers above, it is as if what was expressed by the adolescent has been already said, touched, imagined, known in other place and by other person. On the contrary, in the invention, observed in the last two answers, what is assimilable from the object is its differential that, for its strangeness, affects violently one or more faculties and causes the invention of the thought.

In Papo Reto, another situation, now from the Internet scenario, which also can be considered as example of elements inclusion for the inventive learning to happen, occurs in Mari's case. "She has been dating for two years, but loves sexting, that is, exchanging text messages or erotic pictures through Internet." The question then brought is whether Mari would be or not cheating her boyfriend and why.

In this context, the invention of the thought is not restricted to the solution of problems, as in Andy's case, but it is translated in the formation of concepts, according to what is observed in the answers given to Mari's case.

Of course it is betrayal. Sending pictures to other men is betrayal, if they are for the boyfriend, that's nice, but if not, it is not ok!" (Giihsiqueira - 18 years old)

It is not betrayal because there was no physical contact. What if the boyfriend watches porn movies? Is he cheating on her too? Of course not! (Luvatic - 16 years old)

Betrayal is, one wanting or not, a kind of personal concept. For some, betrayal is the concrete act, for others, a simple conversation means it. But, if we consider the relationship as a relation of confidence and fidelity, she is betraying the boyfriend's trust for sharing intimate and sexual things with other people. I, personally, believe it to be betrayal. (Kath - 17 years old)

The configuration of problems that may create other concepts does not happen with the situations already disposed in the game. It may happen also in the player's experience that, with higher scores, gets the status of Collaborator in the Game. Between the solution and the invention of problems, there are differences in terms of the experience of inventive learning. When the problem is solved, a priori it already exists, as well as the ways to solve it. By solving this problem, it disappears and, with it, the impulse, the force that leads to the thought. In the problematization, on the other hand, the problem is perpetuated, one asks about each one's relation with the problem or situation, as it is possible to see in the questions below, posted by the Collaborators:

I do not like oral sex and dare not talk to my partner about it.

What should I do? (Stivens - 18 years old)

Is the world beautiful? (Tai - 18 years old)

Do you like yourself? (Fau - 18 years old)

Unlike the previous answers given to the game's situations, these questions are anchored in the players' subjectivity. They refer to their affective, sexual relations, relations with themselves and the world. There is something that is outside cognition, which forces the thought to think, which leads the thought to the opposite direction of the significations already given. 


\section{The game enhances the interaction}

In Papo Reto, the players experience situations with other social public, their pairs, who construct an accumulation of encounters with cultural knowledge. These encounters - via the options "I liked", "I disliked", "I did not understand" - although do not favor a very favorable interaction, allow the communication about the situation, with acceptance or rejection of another player's answer.

A more favorable interaction is possible when the player chooses to comment the others' answers, favoring a construction more active of the discourses produced, as in the situation of the School scenario, about the theme Dating. "In a discussion with your girlfriend (boyfriend), you get very nervous and the more you talk, the more she (he) gets quiet. What do you do? An answer to this question is below:

[...] What I always do. I start yelling to see if he hears. (Giihsiqueira -18 years old)

This answer generated several likes and dislikes and comments such as:

Crazy people are who yell lol. There is no need of this, a talk solves everything. I do not think that yelling is the best solution. (Mosquito -16 years old)

Crap! LOL (Steven -18 years old)

That's right. (Debby - 17 years old)

The deepening into the interaction allows the players the construction of affective and intimate discourses, stressing aspects such as violence in relations of intimacy, gender, dialog, argumentations and conciliations. There are still comments in which the interaction is mediated by a written language proper of cyberspace, which interrupts the linear and fixed writing.

In personal interactions, spontaneous concepts appear in PapoReto, which may be elevated to scientific concepts, for instance, when the player chooses to access the area "Do you catch on?" or, when motivated by the interactions, seeks information in other sources and with other people. As in several collaborative pedagogic strategies, the processes of personal relationship, in which the subjects favor the development of the process of other players' formation of concepts, are systematized in the game.

\section{DISCUSSION}

The game in education is not an actual phenomenon, and the paradoxical relation between the relaxation it allows and the seriousness attributed to education is object of reflection. In literature, game's different potentialities are emphasized as favorer of the process teaching-learning: attractiveness and better appropriation of the content, playfulness, interactivity and active role of the student in the process of learning; inventiveness, sharing and involvement.

Many times, the games are used to complement the educative practice, being restrictive to the clarifying of doubts, to the knowledge gaps, to interaction and relaxation. The trajectories are previously established, giving an educative-inventive character that proposes conducts of right and wrong considered ideal, or limiting itself to the association question-answer, which indicates a way that is little open to creation and invention ${ }^{(17-20)}$. In other experiences, one already identifies formats of games with freer trajectories, in which the production of subjective senses is privileged, in higher or lower intensity, coming closer than the concept of game proposed ${ }^{(21-22)}$.

One defines the game as a free and fictitious action, which supposes the leisure and that, if the participation is forced or recommended, stop being game and become coercion. One plays only when wants to play and for the time he/she wants to play. Based on the pleasure of the game, the player is submitted to an alteration of humor, being open to sensations as satiety, boredom and enthusiasm. It is an uncertain activity, because its development and result can not - or should not - be previously determined. It consists in the need of finding or inventing an answer that is free within its rules. The scope of action conceived in the game is essential and explains, partially, the pleasure that it evokes ${ }^{(9)}$. This concept of game is also operated in other experiences that use such strategies in education ${ }^{(6-7,16)}$.

Under such characteristics, the game is conceived as pedagogic device. The device

is a type of hank or skein, a multilinear set, composed of lines of different nature [...]. [Disentangling its lines] in each case is to construct a map, to plat, to go through unknown lands [...] [Such lines] establish the oscillation between seeing and saying, they act as arrows that do not stop mixing things and words, that do not stop conducting the battle ${ }^{(23)}$.

In the device, multilinear elements and forces connect themselves to surpass the limits of the instituted territories and move towards difference. With this movement, one assures the production of new realities, because, by making the lack of completion explicit, qualifies what is about to be done. The device "plays" with the production of truths in favor of life, taking it in its generator potency, to alter different ways of being.

The lines that compound a device may be in others at the same time, making them interchangeable with each other, as the connection between the device game and the device sexual difference here observed. In this context, one observes the potentiality of Papo Reto to establish innovations that seek to interrupt practices and discourses instituted in the sexuality field, reinforcing the existence of new realities, in which the heterosexuality is just one of the possibilities of gender relation.

The Papo Reto Game as a simulator of reality is inserted into the category called Mimicry, one of the four existing in the classification of the games, which are Mimicry, Agôn, Alea and Ilinx. The games of Mimicry category are characterized by the temporary acceptance of an illusion or of a closed and imaginary universe. They consist, mainly, in the incarnation of a character, in the fact that the player "plays to believe, to make him/her believe in himself/herself or to make others believe that he/she is someone else ${ }^{\prime \prime(9)}$.

In Mimicry, the disguise and the mimic are fundamental aspects, as well as the activity, the imagination and the interpretation. It is an imitation, represented by the purpose of 
dissimulating the social character and freeing the true personality. There is the possibility of the subject to surpass the obstacles, to face the matted and confusing laws of daily life, although he/she has the consciousness that the conduct maintained is a simulation, a simple mimic ${ }^{(9)}$.

The potentiality of the games of this category to favor the approach to the sexuality theme with the adolescent is in its invitation to the experience of projection of himself/herself in an activity without consequences in real life. The player may, in this case, try choices, simulate realities moving apart from himself/herself in the imaginary order and approaching himself/herself in the experienced order, (re) inventing ways to deal with questions of his/her everyday life. In this same direction, in an experience that used a game of simulation in education with nursing undergraduates, one also observed the inventive and self-projection potential of simulation. In this experience, the students could test, simulate and (re) create imaginary scenarios, reflecting on himself/herself and on the future profession through the simulated experience of different problem situations proper of the nurse acting ${ }^{(8)}$.

In Papo Reto, the everyday situations brought in the game, apparently superficial and insignificant, are rich in signs that which exercises a direct action on the ways of subjectification $^{(24)}$. The disturbing and unpredictable character of the game, the "losing time" and its narrow proximity to what the adolescents experience are the betting for it to exercise enchantment and exaltation on the player.

The signs present in the situations of Papo Reto, such as, for instance, in Andy's case, are inseparable from the objects that emit them: they remit immediately to the force of spontaneity and happiness, to the image of the forms of a body and to the weight of the coercion exercised by social rules. The signs then emitted are mundane and sensitive and, for their materiality, exercise a type of violence on the thought, they carry the mark of necessity, conduct the people to the search for the sign's essence ${ }^{(10)}$.

On the other hand, in Mari's case, which approaches sexting and betrayal, besides the mundane and sensitive signs aforementioned, one highlights the presence of the amorous signs, which are the immaterial ones, susceptible to mistakes, powerful, able to cause pain and suffering to people. For the emotion and the affections produced, the amorous signs emitted make Mari's case to work as a problem, provoking need of creating concepts on betrayal.

A concept is understood as a multiplicity, a singularity, which always leads to a problem - or problems - without which it would not have sense ${ }^{(25)}$. The conceptual plans on betrayal created by the adolescents based on Mari's case are touched by other concepts' components, such as trust, fidelity, desire, control, physical contact, feelings and intimacy. In a concept, there are pieces and components of others, which suppose other plans, which answer to connectible problems, participating of a co-creation ${ }^{(25)}$.

Not only in the situations preexistent in the game but also in those produced by the players that acquire status of Collaborator, the potential of (re) creation of concepts was observed. The collaborators' questions "if the world is beautiful" and "if you like yourself", for making to think and connect things apparently apart from each other and from the sexuality theme, also allow the creation of concepts and not exclusively the emission of opinions. The concepts intervene on the opinions, on the ordinary flow of ideas; they propose an unexpected redistribution of things and beings.

For their potency of differentiation, such questions also express the search for the true sign. Each sign has two halves: it designs an object and signifies a different thing. In general, the sign's meaning is mistaken for the being or the object that it designs, that it represents ${ }^{(10)}$. However, producing the difference presupposes to break the representation thought, that which privileges the identical, subordinating the expression of difference.

For reaching the point to produce difference, many encounters are necessary - between players, knowledge, ideas, images, institutions, feelings and other types of knowledge. In the area "Do you catch on?", for instance, the players can try encounters with other types of knowledge, more elaborated and distant from the common sense. The most surprising is that, when playing and participating of encounters offered by the game, the player does not feel that may be learning something. By the way, he/she does not play for learning; he/she does it for pleasure, for enjoying himself/herself, for trying an easy and immediate sensation of enjoyment.

On the idea of interaction, one understands that the Game potentizes the interpersonal relations and intensifies the possibilities of the encounter with the other that, in his/her turn, is marked under the sociocultural perspective. For the free expression, the people communicate and are affected. The social other, that brings a cultural knowledge, is essential in the encounters, which initially are located in the immanence of the relation that happens in this world and with the things that are part of it, and not in the psychic interiority of the subject of learning. Only in a posterior moment what was constructed in the relation of learning is incorporated into the psychic reality of the learner, in process designated internalization ${ }^{(26)}$.

The internalization which one talks about refers to the internal, personal and active reconstruction of what happens externally. By internalizing the discourses produced in the game based on the encounters with the other, the player produces his/her own discourse, appropriates what was constructed in the interaction. The game supposes these interpersonal relations in which reciprocal interactions occur, through language from an active subject to others. The players, at this moment, do not put themselves as simple users of a cultural production but as capable to take it actively. The language allows and permeates this process ${ }^{(11)}$.

In the language proper of the adolescents in the game, evoked in the case that shows the discussion of the couple of lovers in which only one speaks and the other remains silent, one observes a collaborative process in the construction of ideas on the themes that appear in the situation of dating presented. This situation intermediates the incidence of the relations between the subjects about the zone of the present development, field of the concepts, ability and habits acquired that are constantly altered and influenced by the zone of proximal development (ZPD). The ZPD constitutes the field of transformations, of the subjective process not familiar to the subject that, however, may understand them, initially through external help to, then, incorporate them definitely into his/her field of action ${ }^{(11)}$. 
In other educative experiences based on the use of games, the collaboration also appears as possibility and productive effect of the game ${ }^{(6,8,16)}$, even related to the ZPD ${ }^{(27)}$. The interaction and the collaborative production emerge as components that intensify the learning, the negotiations and reflections, for the fact that the game "is a communicative doing, which ignores the distance between who plays and who is put before the game ${ }^{\prime(6)}$. In the case of the adolescents, these collaborative activities become even more important, considering the great development and the maturation of the intellectual functions, which form the psychological basis in this phase of life.

\section{Study limitations}

This study was based on the application of the Game with a restrict group of adolescents, students from two distinct cities and from the same type of public school. For proposing theoretical ruptures in this field of knowledge of education, games and their possibilities, it is necessary to amplify and increase the experience developed for new groups of adolescents and other new contexts, including, for instance, students from particular schools, resident in distinct Brazilian regions and states.

\section{Contributions for health field and nursing}

The objective in this article was to describe the potential of the Game in relation to its capacity of activating the simulation of realities, the invention and the interpersonal relations, becoming attractive and stimulating for the adolescents to create a singular route of learning in the sexuality field. One believed in its capacity to implicate the adolescent in problem-based situations, non-directive, without the demand of determined learning or support from a teacher.

One understands that the game brought possibilities for the player to simulate a character, share ideas and experiences on sexuality, without feeling obliged or coerced to the fulfillment of an educative activity. The unpredictability of the answers, situations and comments posted by the collaborators, the possibility to try freely, for instance, the change of sex or characteristics without the weight of a tough educative reality, reinforce the potentiality of the Game so that the adolescents take risks on new ways and become active in the production of discourses on sexuality.

The player can also practice the rupture of the limits that realizes in himself/herself, giving contours to new forms of thinking, feeling and acting. It is still necessary to recognize the importance that the search for pedagogic strategies that favor new ways of subjectification may have to teaching and health, especially for nursing, considering the partnerships with education which have been constructed through PSE.

This study evidenced new points on a known theme - the education and the approach to sexuality with adolescents via the game. It demonstrated to be possible, through the Papo Reto game, characterized by the proposal of provocations, affectation and insertion of problems, the production of knowledge, as well as new models of subjectification in a distinct context in traditional practices of education.

\section{CONCLUSION}

The construction of knowledge derives from a shared action, implicated in mediation between people and of appropriation of the human history's behavioral and cultural ways. The social interaction becomes indispensable for the learning and for the development, because the social relations converge in mental functions.

\section{FUNDING}

São Paulo Research Foundation and Minas Gerais Research Foundation.

\section{REFERENCES}

1. Brasil. Ministério da Saúde. Diretrizes para implantação do Projeto Saúde e Prevenção nas Escolas. Brasília (DF): Ministério da Saúde; 2008.

2. Chaves ACP, Bezerra EO, Pereira MLD, Wagner W. Conhecimentos e atitudes de adolescentes de uma escola pública sobre a transmissão sexual do HIV. Rev Bras Enferm[Internet]. 2014[cited 2016 Nov 11];67(1):48-53. Available from: http://www.scielo.br/pdf/reben/ v67n1/0034-7167-reben-67-01-0048.pdf

3. Nogueira C, Saavedra L, Costa C. (In)visibilidade do gênero na sexualidade juvenil: propostas para uma nova concepção sobre a educação sexual e a prevenção de comportamentos sexuais de risco. Pro-Posições[Internet]. 2008[cited 2016 Nov 11];19(2):5979. Available from: http://www.scielo.br/pdf/pp/v19n2/a06v19n2.pdf

4. Pirotta KCM, Barboza R, Pupo LR, Unbehaum S, Cavasin S. Programas de orientação sexual nas escolas: uma análise das lacunas na implementação de políticas públicas a partir da percepção dos alunos da rede municipal de ensino de São Paulo. RGPP[Internet]. 2013[cited 2016 Nov 11];3(1):190-210. Available from: http://www.revistas.usp.br/rgpp/article/view/97893/96686

5. Souza V. Adolescentes em cena: uma proposta educativa no campo da saúde sexual e reprodutiva. Rev Esc Enferm USP[Internet]. 2011[cited 2016 Nov 11];45(spe2):1716-21. Available from: http://www.scielo.br/pdf/reeusp/v45nspe2/14.pdf

6. Silva LVS, Tanaka PSL, Pires MRGM. Banfisa e (In)Dica-SUS na graduação em saúde: o lúdico e a construção de aprendizados. Rev Bras Enferm[Internet]. 2015[cited 2016 Nov 12];68(1):124-30. Available from: http://www.scielo.br/pdf/reben/v68n1/00347167-reben-68-01-0124.pdf

7. Soares ANS, Gazzinelli MF, Souza V, Araújo LHL. Role Playing Game (RPG) como estratégia pedagógica na formação do 
enfermeiro: relato de experiência da criação do jogo. Texto Contexto Enferm[Internet]. 2015[cited 2016 Nov 12];24(2):600-8. Available from: http://www.scielo.br/pdf/tce/v24n2/pt_0104-0707-tce-24-02-00600.pdf

8. Soares ANS, Gazzinelli MF, Souza V, Araújo LHL. Role Playing Game (RPG) na graduação em enfermagem: potencialidades pedagógicas. Rev Eletr Enf. No prelo 2016.

9. Caillois R. Os Jogos e os Homens: a máscara e a vertigem. Lisboa: Editora Cotovia; 1990.

10. Deleuze G. Proust e os signos. 2 ed. Rio de Janeiro: Forense Universitária; 2003.

11. Vygotsky LS. A construção do pensamento e da linguagem. São Paulo: Martins Fontes; 2001.

12. Malta DC, Silva MAI, Mello FCM, Monteiro RA, Porto DL, Sardinha LMV et al. Saúde sexual dos adolescentes segundo a Pesquisa Nacional de Saúde dos Escolares. Rev Bras Epidemiol[Internet]. 2015[cited 2016 Nov 12];14(suppl.1):147-56. Available from: http://www.scielo.br/pdf/rbepid/v14s1/a15v14s1.pdf

13. Tronco CB, Dell'Aglio DD. Caracterização do comportamento sexual de adolescentes: iniciação sexual e gênero. Gerais, Rev Interinst Psicol[Internet]. 2012[cited 2016 Nov 12];5(2):254-69. Available from: http://pepsic.bvsalud.org/pdf/gerais/v5n2/v5n2a06.pdf

14. Vonk ACRP, Bonan C, Silva KS. Sexualidade, reprodução e saúde: experiências de adolescentes que vivem em município do interior de pequeno porte. Ciênc Saúde Colet[Internet]. 2013[cited 2016 Nov 12];18(6):1795-807. Available from: http://www.scielo.br/pdf/csc/ v18n6/30.pdf

15. Brasil. Estatuto da criança e do adolescente: Lei federal no 8069, de 13 de julho de 1990. Rio de Janeiro: Imprensa Oficial; 2002.

16. Pires MRGM, Guilhem D, Göttems LBD. Jogo (IN)DICA-SUS: estratégia lúdica na aprendizagem sobre o Sistema Único de Saúde. Texto Contexto Enferm[Internet]. 2013[cited 2015 Set 10];22(2):379-88. Available from: http://www.scielo.br/pdf/tce/ v22n2/v22n2a14.pdf

17. Mariano MR, Pinheiro AKB, Aquino PS, Ximenes LB, Pagliuca LMF. Jogo educativo na promoção da saúde de adolescentes: revisão integrativa. Rev Eletron Enf[Internet]. 2013[cited 2016 Nov 13];15(1):265-73. Available from: www.fen.ufg.br/fen_revista/ v15/n1/pdf/v15n1a30.pdf

18. Barbosa SM, Dias FLA, Pinheiro AKB, Pinheiro, PNC, Vieira NFC. Jogo educativo como estratégia de educação em saúde para adolescentes na prevenção às DST/AIDS. Rev Eletron Enferm[Internet]. 2010[cited 2016 Nov 13];12:337-41. Available from: www.fen.ufg.br/fen_revista/ v12/n2/v12n2a17.htm

19. Gilliam M, Jagoda P, Heathcock S, Orzalli S, Saper C, Dudley J, et al. LifeChanger: A Pilot Study of aGame-Based Curriculum for Sexuality Education. J Pediatr Adolesc Gynecol[Internet]. 2015[cited 2016 Nov 13];23(00319-8):S1083-3188. Available from: https://www.ncbi.nlm.nih.gov/pubmed/26409156

20. López IJP, Fernández MD. A school breaks card game improves eating habits in adolescentes. Nutr Hosp[Internet]. 2012[cited 2016 Nov 13];27(6):2055-65. Available from: https://www.ncbi.nlm.nih.gov/pubmed/23588457

21. Araújo RB, Oliveira MMA, Cemi J. Desenvolvimento de role-playing game para prevenção e tratamento da dependência de drogas na adolescência. Psic: Teor Pesq[Internet]. 2011[cited 2016 Nov 13];27(3):347-55. Available from: http://www.scielo.br/pdf/ ptp/v27n3/10.pdf

22. Ionta M. Aprender e ensinar história: os jogos de RPG na sala de aula. Rev Ponto Vista[Internet]. 2010[cited 2016 Nov 13];6:23-9. Available from: http://www.coluni.ufv.br/revista-antiga/docs/volume06/2-Aprender_Ensinar_Historia.pdf

23. Deleuze G. Que é um dispositivo? In: Balbier E, Deleuze G, Dreyfus H, Frank M, Glücksmann. Michel Foucault, filósofo. Barcelona: Gedisa; 1990. p. 155-63.

24. Kastrup V, Tedesco S, Passos E. Políticas da Cognição. Porto Alegre: Sulina; 2008.

25. Deleuze G, Guattari F. O que é a Filosofia? Rio de Janeiro: Ed. 34; 2010.

26. Pascual JG, Justa R. A aprendizagem inventiva no ensino de Psicologia. Arq Bras Psicol[Internet]. 2009[cited 2015 Set 20];61(3):2334. Available from: http://pepsic.bvsalud.org/pdf/arbp/v61n3/v61n3a04.pdf

27. Pinheiro SNS, Damiani MF, Silva Junior BS. O jogo com regras explícitas influencia o desenvolvimento das funções psicológicas superiores? Psicol Esc Educ[Internet]. 2016[cited 2016 Nov 13];20(2):255-64. Available from: http://www.scielo.br/pdf/pee/ v20n2/2175-3539-pee-20-02-00255.pdf 